\title{
Financial Reporting Practices and Investment Decisions: A Review of the Literature
}

\author{
Konstantinos Kapellas and Georgia Siougle*
}

Department of Accounting and Finance, School of Business, Athens University of Economics and Business, Greece

\begin{abstract}
This study presents an effort to summarize evidence on literature about the effect of financial reporting practices on investment decisions. Regulatory interventions/changes impact financial reporting and thus play a significant role on the international comparability/usage of financial statements and as a result on investment decisions. We discuss existing literature regarding the effects of financial reporting practices firstly on the cost of equity capital. We then summarize literature concerning the effect of financial reporting practices on investment decisions as documented in the literature in the areas of earnings management; information asymmetry effects; accounting quality; the effects of the information environment; investment efficiency; over investment -under investment and cash flow sensitivity; stock market efficiency.
\end{abstract}

Keywords: Financial reporting; Investment management; Financial management

\section{Introduction}

This study presents an effort to summarize evidence on literature about the effect of financial reporting practices on investment decisions. Regulatory interventions/changes impact financial reporting and thus play a significant role on the international comparability/usage of financial statements and as a result on investment decisions. We start by describing current literature regarding the effects of financial reporting practices on the cost of equity capital. The cost of equity capital is directly linked to internal or external investment decisions. We then summarize literature concerning the effect of financial reporting practices on investment decisions as documented in the literature in the areas of: i) earnings management, ii) information asymmetry effects, iii) accounting quality, iv) the effects of the information environment, v) investment efficiency, vi) over investment - under investment and cash flow sensitivity. We finally present a number of papers that relate financial reporting practices, capital investments and stock market returns. The rest of the paper is organized as follows; section two presents evidence on the association of financial reporting quality and the cost of equity capital; section three summarize existing literature on the relation of financial reporting and investment decisions; section four presents existing literature on financial reporting, investments and stock returns and section five concludes.

\section{Financial Reporting and the Cost of Equity capital}

It is well-accepted that the cost of equity capital is related to investments decisions (internal or external). Financial reporting practices are affecting the cost of equity capital. A number of research papers investigate the link between financial reporting practices and the cost of equity capital.

Daske [1] investigates whether under internationally recognized standards the firm's financial reporting systems reduce the cost of equity capital of firms applying these standards. He uses a set of German firms that apply internationally recognized standards and investigates the economic benefits of these reporting practices by analyzing their cost of equity capital. Surprisingly, the empirical results suggest that cost of equity capital is higher for firms that apply non-local standards during the adoption or transition period. But this is explained either by the difficulty of estimating the cost of equity capital or by the nature of the adoption process of the international financial reporting standards in Germany.
Daske [1] proposes that future research should analyze the essential variation in the changes in the cost of equity capital of IFRS adopting firms so as to identify under which conditions the adoption of international financial reporting standards leads to measurable economic benefits.

Lee et al. [2] analyze the effect of mandatory IFRS adoption on the cost of equity capital in Europe, based on the rule that the initial mission and main target of capital markets is to provide cheap capital to firms. They refer that: "The former SEC chairman, Arthur Levitt, once stated that 'The truth is, high quality standards lower the cost of capital' [3]".

However empirical evidence did not provide support that the cost of equity capital is reduced in cases that low incentives to establish new financial reporting practices exist, meaning that they are not supported by a strong legal enforcement and economic environment. But they provide evidence that cost of equity capital is reduced for firms in countries with incentives like UK "(Findings do not support the prostandard school of thought, which predicts greater IFRS benefits for smaller countries with lower-quality domestic GAAP. Given that UKGAAP was recognized to be roughly equal in disclosure quality to IFRS)."

In addition to that, Lee et al. [2] demonstrate that the cost of equity capital has been reduced more in the UK for firms which demand greater capital from foreign markets and investors, since financial statements comparability is enhanced and firms seeking foreign capital are benefited by that transition, followed by higher accounting quality and disclosures.

*Corresponding author: Georgia Siougle, Department of Accounting and Finance School of Business, Athens University of Economics and Business, Greece, Tel: +30 2108203911; E-mail: gsiougle@aueb.gr

Received November 30, 2017; Accepted December 15, 2017; Published December 29, 2017

Citation: Kapellas K, Siougle G (2017) Financial Reporting Practices and Investment Decisions: A Review of the Literature. Ind Eng Manage 6: 235. doi:10.4172/21690316.1000235

Copyright: (c) 2017 Kapellas K, et al. This is an open-access article distributed under the terms of the Creative Commons Attribution License, which permits unrestricted use, distribution, and reproduction in any medium, provided the original author and source are credited. 
However, cross-sectional variations still may remain across European countries, even after mandatory IFRS adoption across Europe, setting a common accounting language and imposing comparability across borders. Additionally, institutional differences across Europe are significant in terms of disclosure incentives and accounting quality and cannot be changed by the establishment of new accounting standards. In particular, they show that in the first two years after the transition period of mandatory IFRS adoption, firms in countries where equity-based financing and higher disclosure quality are well established like UK, are benefited more from IFRS adoption.

Finally, they argue that over a long period firms will be benefited by the mandatory IFRS adoption even in countries with low accounting quality characterized by local accounting standards. The international accounting harmonization in a longer period encourages firms that used to be debt-based financed to become equity-based financed. This means that firms in countries with previously low-quality financial reporting incentives and low enforcement framework would possible increase their compliance to new standards so as to provide enhanced information to outside investors through IFRS and be benefited by additional cheaper capital supply. Additional regulatory interventions would improve incentives and enforcement, even for firms in countries with low financial reporting incentives and weak legal enforcement of the economic environment.

In brief, this study emphasizes that accounting standards are not only a part of the regulatory system that governs the relationship between firms and investors. IFRS may well be fitted to stock-marketbased economies like US and UK, but may not be fitted to other forms of economies with different institutional regulations, social, political and commercial practices like European countries. These differences could reveal possible disagreements between US (FASB) and EU (IASB) about the appropriateness of the new accounting standards.

Contributing to the same stream of literature, Li examines the effects of mandatory IFRS adoption to the cost of equity capital, and whether the cost of equity capital is reduced after the mandatory IFRS adoption in the European Union [4]. The mandatory IFRS adoption establishes a unique and uniform set of accounting standards to be followed by firms, which enhance information comparability and financial disclosure and as a result it is expected the cost of equity capital to be reduced.

Empirical findings support that mandatory IFRS adoption significantly reduces the cost of equity to firms after 2005 and that for voluntary IFRS adopters after 2005 the cost of equity does not significantly change.

Prior to 2005, comparing voluntary versus mandatory IFRS adopters, cost of equity capital is significantly lower but this difference is eliminated after 2005. In brief, based on a sample of EU firms, Li [4] finds evidence that firms after the mandatory IFRS adoption increase disclosure and enhance comparability which has as a consequence the cost of equity capital to be significant lower.

She further identifies that in countries with strong legal enforcement mechanisms, mandatory IFRS adoption reduces significantly the cost of equity capital and the effects depend on the strength of the legal enforcement of the economic environment.

$\mathrm{Li}$ [4] contributes to the literature providing new results to the economic consequences of mandatory IFRS adoption, since there is no adequate evidence on its capital market effects and also identifying the implications of mandatory IFRS adoption by providing new evidence on the significantly lower cost of equity capital. Furthermore, this study contributes to the literature by incorporating the economic consequences of improving the regulations in terms of disclosures. It highlights that it is important for institutions to have financial reporting convergence and accounting information quality which positively affect cost of equity capital (Appendix).

\section{Financial Reporting and Investment Decisions}

\section{Earnings management}

Extended effort of research in literature is spent in the area of financial reporting quality that is related to "earnings management". The consequences of earnings management relate to the decisions taken by investors, managers, directors, and regulators. Of great interest is the research area that addresses how earnings management affects capital investment decisions. There is also an emerging literature which explores the role of financial statement information in investment decisions. These lines of thinking leads McNichols and Stubben to examine whether intentional distortions in accounting numbers affect investment decisions and whether earnings manipulation drives firms to make suboptimal investment decisions [5]. McNichols and Stubben aim to provide new evidence on whether motivated by compensation targets or capital market expectations, accounting misstatements distort the investment decision making process of the firms by incorporating the manipulated accounting numbers, which means "misreporting to investors results in resource misallocation" [5]. McNichols and Stubben ask whether decision making process is distorted since earnings management ends up with manipulated information incorporated in the internal financial reporting and internal decision making process and suggest that earnings management significantly affects firms' investment decisions [5]. Relating the economic consequences of earnings management and resource allocation, they contribute to the literature suggesting that earnings management can lead to inefficient investments which is a direct cost to investors. This study also contributes to the literature identifying that earnings management affects decision making within firms and not only investment decisions made by outside investors based on financial reports. Firms during overstated earnings periods tend to overinvest in property, plant, and equipment or in general fixed assets, which means that there is an impact and change on internal decision making process of investors' expectations of the firm's fundamentals, but also the fundamentals have been changed too.

Li and Tang investigate how discretionary accruals or accounting earnings quality affects future investments and mainly investment efficiency [6]. They suggest that firms with large positive discretionary accruals show suboptimal investment decision and allocation of their resources.

$\mathrm{Li}$ and Tang find that firms having large positive discretionary accruals investments in fixed assets are less sensitive to internal cash flows [6]. They also find that firms with large positive discretionary accruals have a lower return on investments on assets, since the firms inefficiently allocate resources to fixed assets.

Firms with large positive and negative unsigned discretionary accruals have a higher external cost of capital. But "firms with large positive discretionary accruals have a lower stock return in the future and lower external cost of capital at the time of portfolio formation". This happens because investors, at the time of portfolio formation, are unsure about the incentives of managers about financial reporting.

$\mathrm{Li}$ and Tang contribute to the literature by providing alternative 
explanations that firms with lower earnings quality are characterized by less efficient investment decisions and lower future cash flows [6].

Based on these studies there are potential areas for future research focusing on the identification of how the large positive discretionary accruals drive to less efficient investment decisions, like underinvestment or overinvestment.

\section{Information asymmetry}

Corporate finance provides compelling arguments that firmlevel investment policies become suboptimal in the presence of information asymmetries between managers and capital suppliers. Myers and Majluf consider that a firm in order to undertake a valuable investment opportunity must issue common stock to raise firm's cash [7]. Additionally it is considered that management knows more about the firm's value than outside investors. They suggest that firms may refuse to issue stock and this has an impact that they do not benefit from existing investment opportunities.

They have developed, under these assumptions, an equilibrium model of the issue and invest decision. The model suggests explanations like that firms tend to rely on internal generated cash flows and to prefer debt than equity if external sources of finance are needed.

In the financial environment if there is no information asymmetry then internally generated cash flows should not directly affect investment decisions. But if information asymmetry dominates in the financial environment between managers and investors then firms would rely on internally generated cash flows on investment decisions so as to finance their investment projects.

Of course, banks have more access to private information about firms comparing to other public debt holders. It is expected that internally generated cash flows are less significant in investment decision making process for bank-debt financed firms rather than public-debt financed. Debt covenant that limit managers' opportunistic investments, through the debt agreements, gives banks the opportunity to mitigate information asymmetry problems, but also reduces the significance of internally generated cash flows on investment decisions.

Beatty et al. extend the research that examines the effects of accounting quality on firms' investments, discussing the relation between financial frictions and investment decisions [8]. Their study provides empirical evidence about the effects of the source of financing to investment decisions, supporting that accounting information reduces financing frictions, identifying that banks reduce financing frictions through informational and monitoring ways, which means either having access to private information or engaging in direct monitoring.

Beatty et al. attempt to reconcile that enhanced accounting quality helps creditors to lower information asymmetry, which means that accounting quality should enhance investment efficiency even for debtfinanced firms [8].

They identify the effects of lenders' private information and the effects of monitoring on the financial reporting quality and how this quality enhances investment efficiency. In particular, Beatty et al. analyze the impact of private information and monitoring to cash flow sensitivity of investment and especially the internally generated cash flows [8]. Moreover they explore how this sensitivity is reduced by the enhancement of financial reporting quality. They conclude, only for financially constrained firms, that private information not only lowers the investment-cash flow sensitivity, but also lowers the significance of financial reporting quality. They further find that debt covenants restrict capital expenditures and reduce information asymmetry related on investments and this is a way for the importance of financial reporting quality to be eliminated.

In addition to that, empirical results suggest that the importance of financial reporting quality is at the highest level whenever information asymmetry is the largest level. However, the significance of financial reporting quality is lowered whenever debt covenants are applied or in general there is private information access. Empirical evidence also support that the significance of financial reporting quality is lowered whenever banks having access to private information reduce investment cash flow sensitivity.

\section{Accounting quality}

Academic literature investigates in depth the effects of the efficiency of firm-level capital investments from accounting quality. Researchers have extensively studied how investment decisions and economic growth are affected by financial frictions, like when liquidity constrained firms cannot get external financing for their investments and are obliged to rely more on their internally generated cash flows.

Capital rationing generated by "the information asymmetry between managers and investors", and agency problems generated by "the conflict of interest between managers and shareholders", explain that managers may proceed to capital investments even with marginal return equal zero, or to make consumption and create "empire buildings" rather than to give back excess cash to shareholders, which is expected in perfect capital markets, whenever there is no significantly positive investment opportunities.

Moral hazard models suggest that "outside financing can dilute managements' ownership stakes, thereby exacerbating incentive problems that arise when managers control the firm but do not own it". "This ex post incentive problem reduces the amount of capital supplied ex ante".

Adverse selection model suggests that "if managers are better informed than investors about a firm's prospects, they will try to sell overpriced securities". As a result "rational investors will, in response, increase the cost of capital, thus decreasing the amount demanded. Therefore, in both cases, frictions operate to reduce the amount of external capital supplied to the firm".

Firms with internally generated cash can moderate these effects, since capital investment is correlated with internally generated cash. External financing forces managers to be monitored and disciplined by capital providers, but financing projects by internally generated funds permits firms to avoid this monitoring and allows managers to overinvest. These imperfections exist because of information asymmetry between managers and investors. Higher financial reporting quality enhancing perfect monitoring should minimize agency problems and as a consequence investment decisions would not be affected by internally generated cash flows.

Transparent accounting "should reduce both adverse selection and moral hazard by improving contracting and monitoring" and thus "higher financial reporting quality would enhance investment efficiency by mitigating these frictions".

Biddle and Hilary examine how financial reporting quality relates to firm-level capital investment efficiency [9]. Focusing on economic productivity on the investments in productive assets they believe that higher financial reporting quality should enhance investment 
efficiency by reducing information asymmetry between managers and investors. Since accounting information is the main input for capital markets to operate, information asymmetry can generate either liquidity constraints or excess cash, which generate inefficiencies in the investment decisions making high accounting information quality to mitigate.

Biddle and Hilary explore the association between financial reporting quality and investment efficiency [9]. Using as proxy investment-cash flow sensitivity, they predict that greater financial reporting quality mitigates investment cash flow sensitivity. They set empirical tests across countries. They measure financial reporting quality using as measures earnings aggressiveness, loss avoidance, earnings smoothing and timeliness. Consistent with their hypotheses, Biddle and Hilary find that higher financial reporting quality mitigates the investment-cash flow sensitivity both across and within countries and those firms with a lower earnings quality have enhanced investment cash flows sensitivity [9].

They find that the impact of internally generated cash flows to investments is lower when accounting quality is high. Their study considers also that the effect of higher accounting quality on investmentcash flow sensitivity should be stronger in economies where financing is mainly provided by capital markets than those provided by debt, since banks obtain private information and monitor firms.

Their study contributes to the existing literature with empirical evidence concerning how accounting financial and institutional features affect capital markets and as a consequence affect capital investments and investment decisions.

\section{Information environment}

Focusing on multinational corporations (MNCs) and their investment decisions, there is a literature about MNCs that mitigate information frictions assisted by the external information environment. Existing research emphasizes on cross border information frictions between parent companies and subsidiaries, since there is a need for parent companies to use accounting information and to monitor and evaluate their subsidiaries' investment decisions. Shroff et al. contribute to the academic research on the real effects of accounting information, testing whether MNCs parent companies use the external operating information environment of subsidiaries to monitor their subsidiaries' investment decisions [10]. They hypothesize that information from external economic environment can be used to improve managerial investment decision making process. They also hypothesize that rich information environments positively influence the investment decisions of subsidiaries and negatively the poor information environments.

Shroff et al. find empirical evidence that the better information environments significantly affect the subsidiary's investment sensitivity to growth opportunities [10]. The information environment has greater impact on investment growth opportunity whenever the parent company is involved in its subsidiary's investment decision-making processes or whenever there are greater cross-border frictions.

They also provide new perspectives on that the external economic information environment is a significant assistance to lower the crossborder frictions. Subsequent research opportunities in terms of MNCs are opened, such as the examination of corporate governance of MNCs and the interaction with the economic environments so as to eliminate cross-border frictions.

\section{Investment efficiency}

A long line of academic literature studies investment efficiency and a lot of recent papers indicate that enhanced financial reporting quality may have positive economic implications such as increased investment efficiency. Prior studies suggest that higher financial reporting quality reduces information asymmetry, moderates moral hazard and adverse selection and improves investment efficiency, but does not examine whether it reduces over- or under-investment. Biddle et al. [11], after integrating their prior studies $[9,12]$, extend this stream of research by analysing how financial reporting quality relates to investment efficiency and contribute to the literature by examining whether higher financial reporting quality is related with lower levels of over- and under-investment.

Empirical evidence support that higher financial reporting quality is positively associated, either with firms with high cash availability, unlevered and lower investments or with firms with shortage of cash, highly levered and higher investments. Furthermore, Biddle et al. support that "firms with high financial reporting quality invest less when aggregate investment is high, and invest more when aggregate investment level is low" [11].

The conclusions suggest that financial reporting quality is enhanced by mitigating frictions such as moral hazard and adverse selection and as a result investment efficiency is improved.

Another study focusing on investment efficiency is that of Verdi [12] which examines the effects of the level of financial reporting quality to investment efficiency providing theoretical support and empirical evidence.

Verdi [12] hypothesizes that "higher financial reporting quality can improve investment efficiency by reducing information asymmetry in two ways". First, between the firm and the investors which have positive effects to cost of equity capital when firms raise funds and second, between investors and the manager which has positive effects to the cost of monitoring managers.

In brief, literature suggests that information asymmetry between the firm and investors, as well as between investors and managers can impede efficient investment, since it affects the cost of raising funds and project selection.

Financial reporting quality is defined as the capability of financial statements to provide accurate information presenting firms performance, operating profitability, expected cash flow to investment community and especially to shareholders in order to make better equity investment decisions.

Investment efficiency is also determined as "when a firm needs to raise capital in order to finance its investment opportunities or when the firm decides to raise capital, and there is no guarantee that the correct investments are implemented".

Financial reporting quality reduces information asymmetry, limits adverse selection cost, limits agency cost, reduces external financing cost and then improves investment efficiency. Moreover, these positive effects of financial reporting quality to investment efficiency are clearer for financial constrained firms.

Based on that "financial reporting affects both adverse selection and agency conflicts" Verdi predicts and finds "an average negative relation between financial reporting quality and both underinvestment and overinvestment" [12].

Cross-sectional tests of this study suggest that the positive effect of financial reporting quality on overinvestment is due to agency costs limitation and identifies that "financial reporting quality is more 
strongly negatively associated with overinvestment for firms with large cash balances and with dispersed ownership". Verdi [12] suggests that financial reporting quality is more positively associated with investment efficiency for firms with poor information environments (in particular with low analyst following) and for firms with high bid-ask spreads, which may indicate lower levels of disclosure and higher cost of capital for firms with low analyst following. Investment efficiency is also associated with the price informativeness (an ex-post measure of information quality)

Verdi [12] finds a negative relation between financial reporting quality and underinvestment or overinvestment and suggests that financial reporting quality mitigates underinvestment (overinvestment) through the reduction in uncertainty related to economic fundamentals (economic fundamentals and managerial choices).

For the hypothesis that the relationship between underinvestment and financial reporting quality is stronger for firms that face financing constraints, Verdi [12] finds mixed evidence and cannot conclude that "financial reporting quality is associated with lower underinvestment due to the reduction in the information asymmetry between the firm and investors and the reduction in the cost of raising funds for financially constrained firms".

This significant study contributes to the academic research area on the economic consequences of enhanced financial reporting by demonstrating that there is an association between financial reporting quality and more efficient investment, such as increased liquidity, lower costs of capital and higher firm growth.

The economic consequences of such as increased investment efficiency of enhanced financial reporting quality is also investigated in terms of the type of firms like public traded or private and in terms of developed and developing countries and capital markets.

Prior research summarizes first that financial reporting quality is positively associated with investment efficiency for large, public companies; second, public companies are characterized by higher financial reporting quality systems than private companies; third, financial reporting has significance in developed countries. Chen et al. [13] combine the above and examine the relationship between financial reporting quality (FRQ) and investment efficiency on a sample of private firms in emerging markets.

Chen et al. provide evidence that financial reporting quality is positively related with investment efficiency which is negatively related to both underinvestment and overinvestment [13]. Moreover, their findings indicate that financial reporting quality is more positively associated with investment efficiency in cases where banks are the main source of finance for firms' investment and for firms that are less positively associated with incentives to manage earnings for tax purposes. In addition, higher financial reporting quality is likely to lower information asymmetry for private firms which are seeking external financing. The investment efficiency of private firms is more sensitive to financial reporting quality for those firms seeking bank financing.

In brief, conclusions of this study support that financial reporting quality has a statistically and economically significant relationship with investment efficiency, a significantly negative association with under and overinvestment and the importance of financial reporting quality is increasing with the degree of bank financing. Based on these results this study contributes to prior literature on the economic consequences of financial reporting quality enhancement.
Another dimension of academic literature in the area of investment efficiency and particularly the relationship among over-investment, shareholding structure, and firm value is examined by Huang and Yan exploring "the efficiency of resources after state-owned and private enterprise acquiring credit from the view of shareholding structure" [14]. They find empirical evidence based on public companies from Chinese Securities Market and compare them with Chinese stateowned enterprises.

Huang and Yan (2012) find that state-owned enterprises can obtain credit resources more easily in comparison to private enterprises because of credit discrimination" [14]. They additionally find for stateowned enterprises that the more easily they obtain credit resources the less firm value they get because they are more likely to over-invest, which reduces their firm value.

This study contributes to academic literature by adding value to the effort of the state-owned enterprise into strictly executing investment standards, so as to improve the quality and efficiency of investment, guiding the private capital to participate in this reform effort. Also by identifying many factors which influences the credit resources allocation efficiency of the state-owned enterprise.

\section{Overinvestment-underinvestment and cash flow sensitivity}

Theory supports that there is a positive relationship between investment expenditure and cash flow. Many measures of free cash flow and over-investment are developed for testing the agency based explanation. In theory where there are perfect capital markets, there is no association between firm level capital investment and internally generated cash flows. However, firms operate in real world, where there are no perfect capital markets, due to frictions of capital markets that hinder management's ability to raise cash from external capital markets. Additionally, there are important transaction costs to monitor managers so as to make sure that free cash flow is indeed distributed to external capital markets. But all these frictions of capital markets give support to a positive association between internally generated cash flow and firm capital investment and.

Richardson [15] introduces a better measure of free cash flow and over-investment constructs through the incorporation of an accounting-based measure of growth opportunities. Richardson examines the extent of firm level over-investment of free cash flow [15] The findings suggest that firms with the highest levels of free cash flow are more likely to over-investment.

Previous studies provide evidence about the factors that restrict over-investment of free cash flow like dividend payments, equity structure, debt constraints, government intervention and governance structures which all have a significant influence on the relationship between the free cash flow and level of overinvestment.

Furthermore, previous studies about corporate governance structures, support that board independence is related to firm's propensity of paying dividends and directors' structure improve the monitoring of managerial decisions. However, there isn't much empirical research about whether characteristics of independent director affect the relationship between corporate free cash flow and level of over-investment till now.

Chen and Liao study the relationship between free cash flow and over-investment and the moderating effects of the characteristics of independent directors [15]. Chen and Liao measure the above relationship using an accounting-based framework and then make empirical analyses and examine the moderating effect of characteristics of independent directors on the relationship [16]. 
This research study concludes that the independent directors play an important role in restricting the enterprise management to over invest, and the education level and board meeting attendance rate of the independent directors make a significant moderating effect on the relationship of over-investment and free cash flow. This study is based on the phenomenon of overheated economy in the process of economic development in China context to extract empirical evidence.

Empirical results show existence of over-investment in Chinese listed companies and that free cash flow has a positive correlation with the over-investment. More specifically, this study suggests that in China independent directors play a significant role in restricting overinvestment, and under different conditions the degree of restricting effects varies.

The contribution of this study to the literature is focused on corporate governance, as independent directors play a certain role constraining inaccurate decision-making of enterprise management. Therefore, corporate regulations should strengthen the construction of the independent director institution and appoint those who are highly educated and actively take part in the meeting of the board of directors to give full play of the supervision utility of the board of directors.

Ffinancial economics literature has documented the sensitivity of investment expenditures to internal cash flows as another research dimension identifying the source of free cash flows. The authors investigate the association between investment cash flow sensitivity and economically significant distortions in the level and timing of investment expenditures [17]. The authors examine the economic significance and the underlying factors of the investment and financing distortions that are associated with investment cash flow sensitivity [17].

They firstly identify firms that have relatively high and low investment cash flow sensitivity and then they examine "the differences in the dynamics of their investment and methods of financing across periods of high and low cash flows".

They suggest that there is an association between investment cash flow sensitivity and both underinvestment in cases cash flows are low and overinvestment in cases cash flows are high. More precisely they suggest that cash flow sensitive firms face financial constraints. The authors demonstrate that firms' access to capital supply from financial markets or debt is in relation to cash flow availability [17].

Their findings indicate that firms which have high investmentcash flow sensitivity can stand binding financial constraints in the years that their cash flows are low. In the years that cash flow is low, external capital is significantly less accessible and therefore these firms significantly underinvest in comparison both to their industry counterparts and to firms with lower investment-cash flow sensitivity.

Capital structure of the firms brings an additional research approach of investment expenditure signaling also overinvestment and underinvestment situations.

There is a long debate in academic and business world about the capital structure characteristics or in more detail the value and the quality of assets, equity, debt and firm's value. It is frequently identified that equity value is not always a positive function of firm value. A simple example of that case may be the transfer of wealth from debtholders to shareholders by trying to reduce debt value and leave firm value unchanged. Another dimension of management that influences firm's value is the biased selection or decline of investments (and in general evaluation of possible investment opportunities) by the conflict of interest among managers, shareholders and debtholders which is generated by debt financing, or leverage.

Cariola et al. analyze different capital structure strategies [18]. They refer that the conflict of interest among managers, shareholders and debtholders drives management to defend only its interests by changing investment selection process, ignoring performance, profitability and return levels and overlooking low risk levels of investments. This totally ignores shareholders and debtholders' interests.

Cariola et al. investigate the interaction between investment decisions (over-investment, under-investment), and financing decisions through the window of creating value [18]. Cariola et al. confront the effects and their implications on firm governance activities presented by recent researches and then they summarize the main financial proposals of prior literature that can diminish their impact.

The contribution of this paper lies in investigating and documenting conclusions about the consequences of investments selection choices related by the financing choices. Additionally this study adds value to the research effort about capital structure effects on firm value. Finally, this study refers that future research should examine how corporate governance characteristics influence capital structure choices and finally firm value.

Following theories in terms of investment decision and the existence of capital-market imperfections like information asymmetry between the main stakeholders. Morgado and Pindado test the occurrence and provide evidence that there exists the optimal level of investments (or the quadratic relationship, rather than linear, between firm value and investment) [19].

Underinvestment and overinvestment mean lower and higher levels of investments than the optimum. Moral hazard and adverse selection generated by the conflict between bondholders and shareholders or between current and prospective shareholders drives firms to underinvestment.

Finally, the study of Morgado and Pindado conclude that profitable investment opportunities give firms the opportunity to enhance their performance level by investing in large scale projects whereas firms without such opportunities cannot reach performance levels as the previous ones, since the number of profitable investment projects is not adequate [19].

Furthermore, in the research area about the relationship between corporate investment and internally generated cash flows under financing constraints, Bushman et al. document that existing research analysis and results of investment-cash flow sensitivities in relation with financial constraints are influenced by the way cash flow is calculated incorporating additional changes in working capital, due to accrual accounting mechanisms [20].

Bushman et al. clarify that academically the level cash flow is measured as the accounting earnings before depreciation (EBD), which contains cash flow from operations, the cash element and the accruals of working capital, the non-cash part and refer that the noncash element of cash flows is related with investment in inventory and accounts receivable assets [20]. Bushman et al. support that the already analyzed by literature cash flow sensitivity can be further analyzed as the sensitivity of investment and accounting earnings before depreciation, which is related mainly by the non-cash element, the investments on working capital rather than by the original cash element (the cash flow from operations) [20]. 
If firm capital investment is enhanced, an increase in non-cash working capital items such as inventories and accounts receivable is expected to be identified.

This study adds new research approaches to investment cash flow sensitivity by incorporating more financing constraints and identifying the non-cash element of research measurement of cash flow to identify the impact of investment and accounting earnings before depreciation sensitivity in order to make more robust conclusions.

Mizen and Vermeulen try to identify the role of the financial and industrial environment and firm's characteristics as creditworthiness and size [21]. They provide empirical evidence of the significant effects of creditworthiness to investment cash flow sensitivity. By selecting firms from each country as similar as possible, they find that the difference in sensitivity to cash flow in each country is insignificant and therefore it is not confident to support that the financial reporting systems of these countries are responsible for the differences in cash flow sensitivity of investment.

They further explore and find that key characteristics of industrial sectors in which firms operate such as size, market characteristics such as export based orientation, competition, production issues, internal competition between intermediary and final products due to production line characteristics force firms to be investment cash flow sensitive. Instead they present results to demonstrate that business industries labeled by high sales growth and operating profits are not sensitive at all to cash flow. On the other hand they find that industrial sectors characterized by low performance are strongly sensitive to cash flow.

Pawlina and Renneboog investigate the investment-cash flow sensitivity and particularly try to identify if the agency costs of free cash flow affect investment decisions when managers overinvest or if the asymmetric information affects investment decisions when managers, owning equity, underinvest possibly due to market demands of high a risk premium [22].

They provide evidence that investment decision process which is based on cash flow availability is mainly due to agency problems and using a sample of UK firms document that agency costs are the main reason of investment cash flow sensitivity.

Firms in which insiders do not own shares or own just a small percentage, have high cash flow sensitivity, but when insider control rises cash flow sensitivity is reduced. On the other hand, firms with outside blockholders reduce the cash flow sensitivity of investment and mitigate informational asymmetry between firms and capital markets via effective monitoring. Finally their conclusions suggest that there is a negative relationship between the investment-cash flow sensitivity and corporate efficiency (Tobin's q ratio).

This study indicates future research in two directions, first supports that there is a need to make an effort to incorporate remuneration of managers and turnover in the investment model so as to analyse to what extent the disciplining devices have enhanced the efficiency of investment policies, and second to analyse the changes of the investment cash flow sensitivity as a consequence of voluntary improvements of financial corporate disclosure.

\section{Financial Reporting, Investments and Stock Returns}

Increased expenditures in investment should be, under conditions, viewed favorably since higher investment expenditures may be the outcome of greater investment opportunities. They may also indicate that the capital markets, which are important source of finance for the investments, have greater confidence in the firm and its management. However, there is a possibility that public firms announce only those investment expenditures that may viewed favorably by investors.

In theory, increased investment expenditures can provide favorable information when the firm that invests more is likely to have better investment opportunities and unfavorable information when firms that invest more are more likely to be managed by individuals who have a tendency to overinvest.

Stock prices tend to respond favorably to announcements of major capital investment. But although firms tend to invest more following increases in their stock prices, cash flows tend to be the best predictor of a firm's investment expenditures. However, financing choices that are associated with increased investment, such as equity issuances, generally result in negative stock returns, while those choices associated with decreased investment, such as repurchases, generally result in positive returns.

Titman et al. document that "a negative relation between abnormal capital investments and future stock returns cannot be explained by either the risks or the characteristics of the firms and are independent of the previously documented long-term return reversal and secondary equity issue anomalies" [23]. Titman et al. support that investors are used to ignore unfavorable information about management actions of public companies and do not drastically proceed to any action whenever spending behaviors and increased investment expenditures are evident [23].

Capital investments represent a fundamental signal for future profitability and stock returns but it is also important in research to explore if firms make sub-optimal investments, and "if market participants understand the implications of managers' incentives to deviate from optimal investment levels when they have the opportunity to do so". Li [23] examines this area and particularly whether overinvestment can partially explain the negative association between capital investments, future profitability and stock returns. This study investigates whether the negative association between capital investment and future profitability can be explained by overinvestment incentives.

Empirical evidence of $\mathrm{Li}$ [23] support that "this association is indeed exacerbated when firms have high free cash flow and low leverage, consistent with management empire building incentives, that it is the positive discretionary investment sample that drives the negative association".

Li [23] notices that greater investment opportunities meaning high free cash flow and low leverage, enhance this negative relation, among investment, future profitability and stock returns, which is mainly affected by the availability of positive investment opportunities which drives management to overinvest, rather than lack of positive investment availability, which eliminates any possibility of overinvestment.

Evidence in this study provides an underlying explanation that "managers' empire building behavior is responsible for the negative association between capital investment and future stock returns".

Finally, Li [23] suggests further research in this field should identify how corporate governance and compensation structures influence the negative effects of the relation between investment and future profitability.

Literature has extensively studied investors' behavior in capital markets which focuses on short-term profits and ignores long-term 
Citation: Kapellas K, Siougle G (2017) Financial Reporting Practices and Investment Decisions: A Review of the Literature. Ind Eng Manage 6: 235. doi:10.4172/2169-0316.1000235

Page 8 of 9

investments. However research and development $(\mathrm{R} \& \mathrm{D})$ is considered as long-term investment since it creates new strategic options and new competitive advantages. In addition to that it is evident that firms with significant and continuous investment on $\mathrm{R} \& \mathrm{D}$, that reduce short-term earnings, may be under-valued. $R \& D$ oriented firms are evaluated in depth by investors trying to identify any possibility of overvaluation of their stocks. Saad and Zantout examine the effects R\&D investment to firms' stock price and systematic risk [24,25]. Saad and Zantout refer that "this persistent difference in the results between equal- and valueweighing indicates a difference in the stock price effects of corporate R\&D investment at large versus small size firms" [25]. This study provides empirical evidence that "an investment strategy of going short with the largest size and long with the smallest size sample firms generates statistically significant positive abnormal monthly returns".

Saad and Zantout also investigate the cash flow and valuation characteristics and they identify that low $\mathrm{B} / \mathrm{M}$ ratio and high cash flow ratio characterize large firms. They also measure the number of patents ratio but they do not find any robust empirical results [25]. Additionally the study investigates the post-R\&D changes in some accountingbased measures of operating performance of their sample firms, and supports that "large-size firms show signs of deterioration instead of improvement in these measures following the R\&D expenditures".

Saad and Zantout provide evidence that large-size firms increasing their $\mathrm{R} \& \mathrm{D}$ expenditures significantly over-invest in $\mathrm{R} \& \mathrm{D}$, trying to acquire new technologies using their large internally-generated cash flows and they over-investing [25]. Additionally, investors initially do not recognize the over-investment in $\mathrm{R} \& \mathrm{D}$ at these firms, but when firms report evidence of over-investment in R\&D they find a related pricing anomaly.

This study contributes also to the research debate on whether a free-market economy efficiently distributes resources into R\&D since large-size firms which significantly increasing their R\&D expenditures tend to over-invest in R\&D.

Combining financing investment through debt and over and under investment Braouezec considers leverage as way to finance a part of the investment cost and his model predicts the negative relationship between the leverage ratio and the market-to-book ratio [26]. He shows that under financial constraints underinvestment is not possible while overinvestment is. Also he shows that overinvestment is negatively related with the part of investment financed by equity [27].

\section{Conclusions}

Based on this review of literature of studies trying to relate financial reporting practices and investment decisions we can summarize that the effects of financial reporting practices on investment decisions are apparent based on significant empirical findings. First, cost of equity capital is affected and significantly lowered after IFRS adoption which enhanced financial reporting quality. Second, other indicators of financial reporting quality like earnings management and reporting/accounting quality are relevant to the investment choices, since distortion of accounting numbers drives firms value and determine investment decisions. Third, information asymmetry effect is significantly related as another mechanism helping investment decisions. Forth, combining previous evidence financial reporting quality improves investment efficiency but also is associated with lower over and under investment. Additional research evidence support that cash flow sensitivity directly affects over and under investment. Finally, there is a relation among financial reporting, capital investments and stock market return. Existing literature has provided significant evidence. However, there is a need for additional research so as incorporating additional factors and indicators to study in depth the economic consequences of financial reporting practices on investment decisions.

\section{References}

1. Daske H (2006) Economic Benefits of Adopting IFRS or US-GAAP - Have the Expected Cost of Equity Capital Really Decreased? Journal of Business Finance \& Accounting 33: 329-373.

2. Lee E, Walker M, Christensen HB (2008) Mandating IFRS: Its Impact on the Cost of Equity Capital in Europe (ACCA research report no. 105). Association of Chartered Certified Accountants.

3. Levitt A (1998) The Importance of High-Quality Accounting Standards Accounting Horizons 12: 79-82.

4. Li S (2010) Does Mandatory Adoption of International Financial Reporting Standards in the European Union Reduce the Cost of Equity Capital? Accounting Review 85: 601-607.

5. McNichols MF, Stubben SR (2008) Does Earnings Management Affect Firms Investment Decisions? The Accounting Review 83: 1571-1603.

6. Li KK, Tang VW (2008) Earnings Quality and Future Capital Investment Evidence from Discretionary Accruals.

7. Myers SC, Majluf NS (1984) Corporate financing and investment decisions when firms have information that investors do not have. Journal of Financial Economics 13: 187-221.

8. Beatty A, Liao S, Weber J (2010) The Effect of Private Information and Monitoring on the Role of Accounting Quality in Investment Decisions. Contemporary Accounting Research 27: 17-47.

9. Biddle GC, Hilary G (2006) Accounting Quality and Firm-Level Capita Investment. The Accounting Review 81: 963-982.

10. Shroff N, Verdi RS, Yu G (2014) Information Environment and the Investment Decisions of Multinational Corporations. The Accounting Review 89: 759-790.

11. Biddle GC, Hilary G, Verdi RS (2009) How Does Financial Reporting Quality Relate to Investment Efficiency? Journal of Accounting and Economics 48 112-131.

12. Verdi RS (2006) Financial Reporting Quality and Investment Efficiency.

13. Chen F, Hope OK, Li Q, Wang X (2011) Financial Reporting Quality and Investment Efficiency of Private Firms in Emerging Markets. The Accounting Review 86: 1255-1288.

14. Huang XJ, Yan H (2012) Shareholding Structure, Investment Efficiency and Firm Value: Evidence from the Chinese Securities Market. Advances in Intelligent Systems and Computing 136: 549-555.

15. Richardson S (2006) Over-investment of free cash flow. Review of Accounting Studies 11: 159-189.

16. Chen S, Liao Z (2012) Free Cash Flow and Over-investment: the Moderating Role of the Characteristics of Independent Director. Advances in Information Sciences \& Service Sciences 4: 141-147

17. Hovakimian A, Hovakimian G (2009) Cash Flow Sensitivity of Investment European Financial Management 15: 47-65.

18. Cariola A, La Rocca M, La Rocca ET (2005) Overinvestment and Underinvestment Problems: Determining Factors, Consequences and Solutions.

19. Morgado A, Pindado J (2003) The Underinvestment and Overinvestment Hypotheses: an Analysis Using Panel Data. European Financial Management 9: 163-177.

20. Bushman RM, Smith AJ, Zhang XF (2011) Investment Cash Flow Sensitivities Really Reflect Related Investment Decisions

21. Mizen $P$, Vermeulen $P$ (2005) Corporate Investment and cash flow sensitivity what drives the relationship? European Central Bank.

22. Pawlina G, Renneboog L (2005) Is Investment-Cash Flow Sensitivity Caused by the Agency Costs or Asymmetric Information? Evidence from the UK European Financial Management 11: 483-513.

23. Titman S, Wei KC, Xie F (2004) Capital Investments and Stock Returns Journal of Financial and Quantitative Analysis 39: 677-700. 
Citation: Kapellas K, Siougle G (2017) Financial Reporting Practices and Investment Decisions: A Review of the Literature. Ind Eng Manage 6: 235. doi:10.4172/2169-0316.1000235

Page 9 of 9

24. Li D (2004) The Implications of Capital Investments for Future Profitability and Stock Returns-an Overinvestment Perspective.

25. Saad M, Zantout Z (2014) Over-investment in corporate R\&D, risk, and stock returns. Journal of Economics and Finance 38: 438-460.
26. Braouezec Y (2009) Financing constraint, over-investment and market-tobook ratio. Finance Research Letters 6: 13-22.

27. Daske H, Hail L, Leuz C, Verdi R (2008) Mandatory IFRS Reporting around the World: Early Evidence on the Economic Consequences. Journal of Accounting Research 46: 1085-1142. 